\title{
Culturally induced range infilling of eastern redcedar: a problem in ecology, an ecological problem, or both?
}

\author{
Aubrey Streit Krug ${ }^{1}$, Daniel R. Uden ${ }^{2}$, Craig R. Allen ${ }^{3}$ and Dirac Twidwell ${ }^{4}$
}

\begin{abstract}
The philosopher John Passmore distinguished between (1) "problems in ecology," or what we might call problems in scientific understanding of ecological change, and (2) "ecological problems," or what we might call problems faced by societies due to ecological change. The spread of eastern redcedar (Juniperus virginiana) and conversion of the central and southern Great Plains of North America to juniper woodland might be categorized as a problem in ecology, an ecological problem, or both. Here, we integrate and apply two interdisciplinary approaches to problem-solving - social-ecological systems thinking and ecocriticism-to understand the role of human culture in recognizing, driving, and responding to cedar's changing geographic distribution. We interpret the spread of cedar as a process of culturally induced range infilling due to the ongoing social-ecological impacts of colonization, analyze poetic literary texts to clarify the concepts that have so far informed different cultural values related to cedar, and explore the usefulness of diverse interdisciplinary collaborations and knowledge for addressing social-ecological challenges like cedar spread in the midst of rapidly unfolding global change. Our examination suggests that it is not only possible, but preferable, to address cedar spread as both a scientific and a social problem. Great Plains landscapes are teetering between grassland and woodland, and contemporary human societies both influence and choose how to cope with transitions between these ecological states. We echo previous studies in suggesting that human cultural values about stability and disturbance, especially cultural concepts of fire, will be primary driving factors in determining future trajectories of change on the Great Plains. Although invasion-based descriptors of cedar spread may be useful in ecological research and management, language based on the value of restraint could provide a common vocabulary for effective crossdisciplinary and interdisciplinary communication about the relationship between culture and cedar, as well as an ethical framework for cross-cultural communication, decision-making, and management.
\end{abstract}

Key Words: biological invasions; cross-disciplinary; culture; ecocriticism; humanities; interdisciplinary; natural science; niche; socialecological systems

\section{CLASSIFYING A PROBLEM}

The philosopher John Passmore (1974) distinguished between (1) "problems in ecology," or what we might call problems in scientific understanding of ecological change, and (2) "ecological problems," or what we might call problems faced by societies due to ecological change. Globally, the loss of grassland (Hoekstra et al. 2005) to processes such as urban development, agricultural production, and woody plant spread represents a challenge about which such distinctions might be made. The spread of eastern redcedar (Juniperus virginiana; hereafter "cedar") in the central and southern Great Plains of North America, for example, might be categorized as a problem in ecology (Meneguzzo and Liknes 2015), an ecological problem (Morton et al. 2010), or both.

As a problem in ecology, the continuing rapid spread of cedar raises questions for ecologists about the underlying processes that drive observed patterns in its distribution, e.g., Why is it spreading? What kept it from spreading in the past? Where is it spreading? How much has it spread? Will it continue to spread? As an ecological problem, cedar's spread raises questions for societies about how people perceive and manage woody plant spread in grasslands, e.g., Is cedar an invasive species? Can its spread be controlled? What are the economic trade-offs associated with its spread? How does cedar management fit into ecological restoration frameworks? Which management tools are available and appropriate? Which policy methods are socially acceptable? In Passmore's (1974) formulation, problems in ecology may be solved through scientific research, while ecological problems may be solved by describing how to reduce the frequency or intensity of the problematic phenomena, often according to knowledge gained through first solving problems in ecology. In other words, science is used for solving problems in ecology, whereas social responses and adaptation are used for solving ecological problems. In the case of cedar, improved scientific understanding of its growth, survival, and spread (Briggs et al. 2002) has informed grassland management efforts, such as fire reintroduction (Weir et al. 2016) and mechanical tree removal (Briggs et al. 2005).

Cedar's spread has also sparked interdisciplinary research within the sciences. For example, Twidwell et al. (2013a) couple physical and ecological fire models to link knowledge from the disciplines of physics and ecology related to fire intensity and cedar mortality, to assess how fire might be more effectively utilized as a management tool. However, adopting alternative management practices requires recognizing conflicting views about the use of fire held by scientists, landowners, ecosystem managers, and regulatory officials, which Twidwell et al. (2016a:364) contend are due to "societal norms that demand complete control over nature and the elimination of extreme disturbance events."

\footnotetext{
${ }^{1}$ Department of English, University of Nebraska-Lincoln, Lincoln, NE, USA, ${ }^{2}$ Nebraska Cooperative Fish and Wildlife Research Unit, School of Natural Resources, University of Nebraska-Lincoln, Lincoln, NE, USA, ${ }^{3}$ U.S. Geological Survey, Nebraska Cooperative Fish and Wildlife Research Unit, School of Natural Resources, University of Nebraska-Lincoln, Lincoln, NE, USA, ${ }^{4}$ Department of Agronomy and Horticulture, University of Nebraska, Lincoln, NE, USA
} 
If social norms, i.e., informal governance institutions (McCay 2002, Hahn et al. 2006), ultimately hinder management efforts to respond to cedar spread, addressing cedar spread first as a problem in ecology, i.e., focusing on scientific understanding, and then applying that knowledge to addressing it as an ecological problem, i.e., focusing on social consequences and responses, might not be the most effective approach. Alternatively, addressing cedar spread as an ecological problem without sufficient mechanistic understanding of it may be even less effective, at least over short time frames. However, given that social norms and practices grow out of cultural concepts and worldviews (Berkes et al. 2000) in indistinguishably linked systems of people and nature, i.e., socialecological systems, or SES (Berkes and Folke 1998), knowledge about past and present human cultures on the Great Plains could assist with simultaneously addressing cedar spread as a problem in ecology and an ecological problem. Human perceptions of cedar's proper place and role have been diverse and dynamic over the past several centuries. Cedar was valued by people as fuel (Witte and Gallagher 2010) and for its spiritual significance (Gilmore [1919] 1991). Presently, the spread of cedar is eliminating grasslands that provide wildlife habitat and livestock forage (Knapp et al. 2008, Harr et al. 2014); however, cedar is also valued for the variety of ecosystem services it provides, which include shelter, i.e., shelterbelts, soil erosion prevention/reduction, wildlife habitat, and carbon sequestration (Brandle et al. 2004, McKinley and Blair 2008).

If culture can be said to contribute rhythm (Holling and Sanderson 1996) to the adaptive dance (Gunderson 2003) between scientific understanding of, and social responses to, cedar spread, then it may be worthwhile to explicitly consider culture when addressing other social-ecological challenges. In practice, this could be accomplished through diversified interdisciplinary efforts that include the humanities (Holm et al. 2015), and which draw upon prior disciplinary and interdisciplinary work within and among the natural sciences, social sciences, and humanities.

\section{INTERDISCIPLINARY APPROACHES TO PROBLEM- SOLVING}

Solving both problems in ecology and ecological problems requires applying knowledge from multiple disciplines (Ledford 2015) and valuing multiple ways of knowing (Kendrick 2003), i.e., epistemological pluralism (Miller et al. 2008). Given the global scale at which the threats to biodiversity and sustainable development now operate (Steffen et al. 2015), long-term, placebased, interdisciplinary collaborations (Collins et al. 2011) that draw from diverse knowledge bases (Ludwig et al. 2001, Turner et al. 2003) may assist with imagining and enacting greater ranges of possible responses (Crona and Bodin 2012). We briefly review, integrate, and apply two interdisciplinary approaches to problemsolving - SES thinking and ecocriticism - to understand the role of human culture in recognizing, driving, and responding to cedar's changing geographic distribution.

Basic tenets of SES thinking connect nature with society and bridge scientific disciplines to better understand and respond to complex social-ecological challenges such as biodiversity conservation and sustainable human resource use under the pressures and surprises of global change (Davidson-Hunt and Berkes 2003, Liu et al. 2007, Folke et al. 2010, Chapin et al. 2011, De Vos et al. 2016). The adoption of problem-oriented frameworks is a common approach to SES analysis (Cumming 2014). Holling (2003:xvii) states, "Sustainable development and management of global and regional resources are not an ecological problem, nor an economic one, nor a social one. They are a combination of all three," and as such, may be addressed with adaptive management (Allen et al. 2011), adaptive governance (Folke et al. 2005), and related collaborative decision-making and management frameworks (Berkes et al. 2000, Hahn et al. 2006, Armitage et al. 2009, Miller et al. 2012, Spoon et al. 2015). Although system adaptability is a major focus of SES thinking, it is not always feasible to adapt to change while maintaining characteristic system structures and functions over the long term. In such instances, transformability allows for the reorganization of the system into a fundamentally different state (Walker et al. 2004, Folke et al. 2005).

In addition to the interdisciplinary tradition of SES thinking in the natural and social sciences, we draw on ecocriticism, an interdisciplinary tradition that has emerged from the humanities. Ecocriticism analyzes and theorizes human culture, language, and literature in the context of ecology and the environment (Heise 2006, Garrard 2012). The language a culture uses to conceptualize its relationship to nature (and "nature" is a term commonly analyzed) may reflect and impact that human group's social norms and behavior. So ecocriticism can be used to address ecological problems, or challenges in how societies respond to ecological change, in part by analyzing the terms through which such problems are culturally named and defined (Garrard 2012). An ecocritical approach to understanding ecological problems involves closely reading the language through which values about nature or ecology are expressed in literary texts like poems, and examining such texts in their cultural, historical, and environmental contexts (see Scigaj 1999, Bryson 2002, Knickerbocker 2012, and Hass 2013). This approach complements research on cognition and values in SES (Jones et al. 2016). The descriptive language and literary devices in poems may illustrate the complex and even conflicting values that shape how a culture recognizes an ecological problem and envisions a solution.

We use the spread of cedar as a case study to integrate and apply these interdisciplinary approaches for understanding the role of human culture in driving ecological change. This unique methodological synthesis allows us to (1) describe the spread of cedar as a process of what we call culturally induced range infilling; (2) clarify the concepts that have so far informed cultural values of cedar and which might be reimagined to effectively address cedar as both a problem in ecology and ecological problem; and (3) actively explore the value of diverse interdisciplinary collaborations and knowledge when applied to social-ecological challenges in the midst of rapidly unfolding global change.

\section{CEDAR SPREAD AS A PROBLEM IN ECOLOGY}

What challenges exist regarding scientific understanding of cedar's past, present, and future geographic distributions, and how might interdisciplinary knowledge contribute to that understanding? To address this question, we start by adopting a general approach from the ecological subdiscipline of landscape ecology: detecting spatial patterns in landscapes and linking them with ecological processes, to improve understanding and predictive ability (Turner et al. 2001). In the case of cedar in Great 
Plains landscapes, general patterns in its geographic distribution include relative historical, i.e., from at least the early 19th century, stability (Bessey 1900) and recent, rapid spread (Meneguzzo and Liknes 2015). Improving understanding of this pattern change, and then extrapolating it into the future, requires examination of the factors that have shaped cedar's historical and current geographic distributions, i.e., ranges. We begin by considering cedar's ecological niche.

\section{Niche}

The ecological niche of a species, sensu Hutchinson (1957, 1978), is defined as the conditions under which it may persist indefinitely, i.e., maintain a stable population and exhibit non-negative net population growth. At large scales, i.e., broad extents, coarse resolutions, and long temporal durations, abiotic environmental conditions, notably climate, interact with the unique physiological requirements of a species to establish its distributional boundaries along environmental gradients. Despite the simplistic appeal of this approach for understanding species' distributions, empirical observations expose shortcomings. Most obviously, a species is generally not present in every location where it is capable of surviving and reproducing (Pulliam 2000, Hirzel and Le Lay 2008). To account for this inconsistency, Hutchinson (1957) divided niche into fundamental and realized components, with the fundamental niche comprising the abiotic conditions, e.g., climate, topography, and soils, under which a species may be assumed to be capable of surviving and reproducing, and the realized niche constituting areas where it is present when biotic interactions, e.g., competition, predation, mutualisms, and facilitation, are also accounted for.

In its fundamental niche, cedar displays broad tolerances in regard to precipitation, temperature, elevation, and soil type, and is the most widely distributed conifer in the eastern United States (Lawson 1990). Thus, grass-dominated Great Plains landscapes are climatically suitable for cedar, a phenomenon observed in relation to grasslands and trees worldwide (Bond 2008). Although it generally does not preclude the presence of cedar in the Great Plains, differences in soil depths, and thus moisture availability, between uplands and lowlands may result in slower spread in upland areas (Ratajczak et al. 2016).

In its realized niche, cedar is generally not limited by biotic interactions, although it may infrequently be defoliated by insects or deer (Odocoileus spp.; Lawson 1990). Cedar does not thrive under dense canopies of other vegetation; however, this is not a common limiting factor in grasslands. Through effects on photosynthetic efficiency, increasing global atmospheric carbon dioxide $\left(\mathrm{CO}_{2}\right)$ concentrations may be conferring $\mathrm{C} 3$ plant species like cedar with competitive advantages over $\mathrm{C} 4$ species (Huntley and Baxter 2013), which include warm season grasses of the Great Plains. However, a substantial degree of uncertainty exists regarding the effects of increasing $\mathrm{CO}_{2}$ (Bond and Midgley 2012) and other facets of climate change (Volder et al. 2013) on treegrass competition. Therefore, based on the above niche definitions and observed cedar tolerances, cedar's fundamental and realized niches are assumed to be quite broad and to largely overlap with each other in the Great Plains.

\section{Niche versus range}

Although useful for differentiating between the roles of abiotic conditions and biotic interactions in determining species persistence (Bruno et al. 2003, Travis et al. 2005, Holt 2009, Wiens et al. 2010), Hutchinson's fundamental-realized niche subdivision does not account for all of the complexities of range. For example, it does not incorporate the effects of dispersal limitations, e.g., physical barriers, habitat fragmentation, and spread lags (Pearson and Dawson 2003, Peterson et al. 2011, Geerts et al. 2013), which means that differences may exist between realized niche and range, depending on the degree to which a species is prevented from reaching areas that are otherwise suitable for its persistence (Soberón and Peterson 2005, Engler and Guisan 2009). Furthermore, a species may temporarily exist but not persist in sink habitats as a result of successful dispersal into areas with unfavorable abiotic conditions or biotic interactions (Pulliam 2000). Therefore, failed, delayed, or successful dispersal may shape a species' range beyond its realized niche.

This distinction between niche and range is based on the bioticabiotic-movement (BAM) framework of Soberón and Peterson (2005), Soberón (2007), and Peterson et al. (2011), which hierarchically integrates the niche concepts of Grinnell (1917) and Elton (1927), and to which the niche concept of Hutchinson $(1957,1978)$ is easily rectified (Fig. 1). Grinnellian niche factors tend to be large-scale and abiotic and Eltonian niche factors to be small-scale and biotic (Soberón and Nakamura 2009). Furthermore, according to Chase and Leibold (2003), the niche definitions of Grinnell and Hutchinson emphasize the effects of environments on species, whereas the niche definition of Elton emphasizes the effects of species on their environments.

Fig. 1. Dynamic representation of the ecological niches and geographic distribution, i.e., range, of a hypothetical species over time, modified from Soberón and Peterson (2005), Soberón (2007), and Peterson et al. (2011). The range (D) is constituted by the intersection of areas in geographic space with suitable abiotic conditions (A), suitable biotic interactions (B), and to which the species is capable of moving (M), i.e., dispersing. The fundamental niche is represented by $\mathrm{A}$, and the realized niche $(\mathrm{RN})$ by the intersection of $\mathrm{A}$ and $\mathrm{B}$. Both range and niche and the components composing them are dynamic, and as such, may fluctuate or shift over time. This animation was created in Microsoft PowerPoint 2013 and converted to a . gif online at https://ezgif.com/.

view video

Under a logistic model of cedar spread, e.g., sigmoid curve (Briggs et al. 2002), the number of cedar seeds available for dispersal in a landscape is proportional to the number of existing mature cedar trees in it. The primary nonanthropogenic dispersal mechanisms of cedar seeds are rain, wind, small mammals, and birds, each of which tend to operate at different spatial scales (Horncastle et al. 2004). None of these seed dispersal modes are noticeably restricted in Great Plains landscapes, although heterogeneity in factors like wind speed and animal population size may affect the location and rate of cedar spread, e.g., by increasing or decreasing mean seed dispersal distance. Lags in spread may thus exclude cedar from portions of its realized niche that are otherwise suitable for it. 


\section{Niche and range shifts}

Over time, niche and range either remain stable or shift (Pearman et al.2008). Niche conservatism, i.e., lack of change in fundamental and realized niches, niche stasis, and niche equilibrium (Wiens et al. 2010), is a foundational assumption of species distribution models, despite the fact that many species, e.g., invasive species, do not exhibit it (Broennimann et al. 2007, Gallagher et al. 2010). Niche shift - the antithesis of niche conservatism - involves any alteration to a species' fundamental or realized niche (Alexander and Edwards 2010) in space (Fitzpatrick et al. 2007) or time (Kharouba et al. 2009). A niche shift may or may not translate into a range shift, depending on the influence of additional factors, e. g., dispersal, that shape range beyond the realized niche.

The expansion of a species' range within its fundamental niche has been termed range infilling (Bradley et al. 2015), and can be quantified as the proportion of a species' climatically suitable area in which it is actually present. In other words, species further from environmental equilibrium exhibit lower degrees of range infilling than species closer to environmental equilibrium (Munguía et al. 2012). Although range infilling can typically be explained by successful establishment and persistence (Schurr et al. 2007), the degree of range infilling for certain species, e.g., invasive species, may also increase with time, as there are more opportunities for successful dispersal, i.e., spread, to surrounding suitable locations (Václavík and Meentemeyer 2012).

Comparisons of the historical (Bessey 1900) and contemporary (Meneguzzo and Liknes 2015) geographic distributions of cedar in the Great Plains clearly indicate that a shift in its range, in the form of increase, has occurred, and is continuing to occur. However, cedar's broad and overlapping fundamental and realized niches mean that its spread throughout the Great Plains is unlikely the result of a niche shift. Similarly, in regard to dispersal limitations, neither slow spread rates nor temporal lags in spread can explain cedar's transition from relative range stability to rapid spread, although both have certainly contributed to spread since it was initiated.

\section{Cultural influences on range dynamics}

Despite the roles of abiotic factors, biotic factors, and dispersal in shaping species' ranges (Peterson et al. 2011), direct and indirect human influences are often equally or more important (Alberti et al. 2003, Folke 2007, Murphy 2013). Although human influence could perhaps be classified as a specialized biotic interaction, its potential to steer and override the effects of other factors warrants its unique consideration (Grimm et al. 2000). This is perhaps most obvious in cities, i.e., urban ecosystems, where the priority of human influence is difficult to ignore (Perring et al. 2013), although cultural effects are not restricted to cities.

One important form of human influence involves the manipulation of disturbance regimes (Turner 2010, González-Moreno et al. 2015). Disturbance regimes describe long-term patterns in local disturbance characteristics, such as their frequency, intensity, extent, and heterogeneity, as well as ecological responses to them (White and Jentsch 2004). Interactions between disturbance regimes and other phenomena, e.g., dispersal, establish successional pathways and structure ecological communities (Pierce et al. 2007, Myers and Harms 2011, Taylor et al. 2012); therefore, human manipulation of disturbance regimes may contribute to the determination of species' ranges.
Human activity, along with biophysical variables like topography, vegetation, climate, and weather, have affected fire disturbance regimes worldwide (Bowman et al. 2011, Hawbaker et al. 2013). In fire-dependent grassland ecosystems of the Great Plains (Bond et al. 2005, Anderson 2006), changes in fire regimes, e.g., frequency and magnitude, over the past several centuries have been driven by both human and nonhuman factors (Fuhlendorf et al. 2009, Twidwell et al. 2013b, 2016a). Historically, people increased the frequency of fire beyond what would have occurred in their absence; however, beginning with 19th-century Native American dispossession and subsequent Euro-American resettlement (Wishart 1995), the direction of this effect was reversed through fire suppression efforts (Courtwright 2011) and the decoupling of patchy spatiotemporal interactions between fire and grazers, e.g., bison (Bison bison; Fuhlendorf et al. 2009). Although there were differences in fire use among Native American cultures (Allen and Palmer 2011, Stambaugh et al. 2013), with presumably different ecological effects, the consequences of Euro-American cultures' fire suppression are evident today in the spread of woody plants in grasslands.

Decreases in fire frequency removed the restraining effect, i.e., demographic barrier, of fire from isolated cedar populations, and they began to spread, first in river valleys and areas with rough topographies, and later in uplands. The transition of landscapes from grassland to woodland states has been discontinuous, not gradual (Ratajczak et al. 2014), as a result of thresholds in firefree time being exceeded (Ratajczak et al. 2016). Crossing these thresholds permits increasing numbers of mature cedars to disperse their seeds into neighboring grasslands, and also decreases the quantity of herbaceous biomass, i.e., fine fuel, available for carrying fires that cause cedar mortality (Fuhlendorf et al. 1996, Briggs et al. 2002). Once grassland-to-woodland ecological state transitions occur, they can be difficult to reverse, even with frequent fire application, a phenomenon known as hysteresis in the study of complex systems (Scheffer and Carpenter 2003). In addition to fire frequency, fire intensity plays an important role in affecting transitions between grassland, savanna, and woodland states (Fuhlendorf et al. 1996, van Langevelde et al. 2003, D'Odorico et al. 2006, Twidwell et al. $2013 a, 2016 b$ ). Although low-intensity fires may not be capable of pushing a savanna or woodland back to grassland, highintensity fires could.

In recognition of the broad, overlapping fundamental and realized niches of cedar, the roles of fire and dispersal in shaping its range beyond the realized niche, and the well-documented influences of humans on fire and dispersal, we interpret current cedar spread in Great Plains landscapes as a process of "culturally induced range infilling," a modification of the term "culturally accelerated sediment accumulation" from wetland studies (Tang et al. 2015). Following human removal of the restraining effect of fire from cedar populations, landscapes have crossed fire-free time thresholds and cedar has been freed to fill unoccupied portions of its realized niche, with the only remaining major constraint being dispersal time lags (Fig. 2). The application of the term culturally induced range infilling to cedar spread helps dissolve the conceptual divide between people and nature by naming and integrating the related regional histories of humans and cedar. 
Fig. 2. Dynamic representation of the ecological niches and geographic distribution, i.e., range, of eastern redcedar (Juniperus virginiana) over time in landscapes of the North American Great Plains, modified from Soberón and Peterson (2005), Soberón (2007), and Peterson et al. (2011). The range (D) is constituted by the intersection of areas in geographic space with suitable abiotic conditions (A), suitable biotic interactions (B), and to which the species is capable of moving (M), i.e., dispersing. The fundamental niche is represented by $\mathrm{A}$, and the realized niche (RN) by the intersection of $\mathrm{A}$ and $\mathrm{B}$. The fundamental and realized niches of cedar are broad and largely overlap; however, cedar was historically prevented from spreading beyond the fringes of its realized niche by the restraining effect, i.e., demographic barrier, of fire. Following fire suppression by Euro-American cultures, cedar began to spread to expand its range within its realized niche, i.e., exhibit range infilling. This animation was created in Microsoft PowerPoint 2013 and converted to a .gif online at https://ezgif. $\underline{\mathrm{com} / \text {. }}$

view video

Fire suppression occurred as fire-suppressing cultures historically supplanted fire-promoting cultures (Stambaugh et al. 2013, Ratajczak et al.2014). Both Native American and Euro-American cultures actively manipulated fire regimes, but in opposite directions (Twidwell et al. 2013b). Given the primacy of fire in shaping cedar's range and the considerable influence of human cultures on fire, it may be inferred that both the historical isolation, i.e., rarity, and recent rapid spread, i.e., commonness, of cedar in Great Plains landscapes are products of human activity. It follows that current ecological state shifts from grassland to woodland can ultimately be traced, via fire suppression and other anthropogenic influences, to the stark and abrupt social transformations of colonization. Furthermore, linking these social and ecological transitions reveals that, at larger spatial and temporal scales, state shifts due to colonization in Great Plains SES are still unfolding. These state shifts manifest through processes like cedar range infilling. This interdisciplinary knowledge about the ongoing social-ecological impacts of colonization, generated in the context of addressing cedar range infilling as a problem in ecology, could be applied to the improvement of fire-based management approaches related to this and other "ecological problems" (Dellasala et al. 2004).

\section{Future range}

Improved mechanistic understanding of cedar's spread aids predictions of its future range. The degree of range infilling achieved by cedar in coming decades is likely to depend largely on whether or not the frequent use of fire as a management tool is integrated into contemporary human cultures of the Great Plains (Fuhlendorf et al. 2008), as it already is in the Flint Hills of Kansas, USA (Allen and Palmer 2011, Ratajczak et al. 2014, 2016). In addition to the primary role of fire in shaping cedar's future range, changes in other factors, e.g., cedar planting and cutting, grazing, precipitation, and atmospheric $\mathrm{CO}_{2}$ concentrations, and in these factors' interactions with fire and one another could have important effects (Fuhlendorf et al. 2008, Bond and Midgley 2012, Volder et al. 2013), especially given regional climate change projections of warmer temperatures and more variable precipitation patterns (Groisman et al. 2012, Shafer et al. 2014). Therefore, interdisciplinary knowledge, particularly regarding human utilization of fire in SES (Laris et al. 2015), will continue to contribute to understanding of cedar's range in Great Plains landscapes.

\section{CULTURAL CONCEPTIONS OF AN ECOLOGICAL PROBLEM}

What challenges exist regarding society's response to cedar's changing geographic distribution, and how might the consideration of literary texts enhance that response? In this section, we delve into the general claim that the social-ecological impacts of settler colonialism, including a historical change between dominant cultures and their practices, have induced the range infilling of cedar. Although a broad consideration of culture helps address cedar spread as a problem in ecology, a more fine-grained analysis of specific literary texts and their contexts clarifies how different cultures have valued cedar. We suggest that without a detailed awareness of how people's concepts and values are culturally conditioned and reinforced in aesthetic, emotional, economic, and spiritual language, it will be difficult for contemporary society to adapt or transform in response to cedar as an ecological problem. Scientifically sound, novel responses may nevertheless use language that subtly affirms rather than questions cultural concepts that contribute to the problem. Alternatively, cultural self-awareness, as well as cross-cultural knowledge, may help enable creative responses to tough ethical questions about human actions, such as the changes human societies induce in other species' ranges. Understanding cultural concepts is a prerequisite for adapting management practices and addressing cedar as an ecological problem.

Ecocritical readings of poetry from the Great Plains may help clarify the human cultural factors, i.e., concepts and values, that influence cedar's range, along with the human social factors, i.e., actions and decisions, and ecological factors, i.e., forces and functions, that do so. We compare two poetic descriptions of cedar from the Nebraska State Poet Twyla Hansen's poem "Survival" (2011) and the traditional Osage ritual "Rite of the Chiefs" documented by Francis La Flesche (Bailey 1995) in the early decades of the 20th century. Despite the differences in culture and time, both texts value cedar as a symbol of life and use metaphors that connect human bodies with cedar trees. We therefore consider if and how terms that link humans and cedars, emphasizing their influences upon each other and their shared effort to live, might enhance society's response to cedar spread as an ecological problem.

\section{"Survival"}

Hansen's "Survival" (2011) addresses the 21st-century spread of cedar by exploring the tension between cultural values of "survival" in emotional, aesthetic, and economic terms (Appendix 1). The poem describes cedar from the imagined, conflicting perspectives of two characters: an ecologist and a poet. These perspectives may be understood as an inner conversation, because Hansen is a poet who has training and experience in horticulture and agroecology. The poem's second and third stanzas portray cedar through the imagined perspective of an 
ecologist. With the help of birds who eat its seeds, the cedar is infilling its range, "Invading / the unplowed field, grassland" and becoming "Prolific as weeds." Hansen describes the ecologist as having a strong and unambiguous emotional response to the cedar's successful drive to survive. The imagined ecologist who manages the prairie with fire to remove cedars feels "contempt" toward them and "gleeful" when they burn.

In contrast to the ecologist who unambiguously "loves to hate" cedars and sees them as "strange and twisted" plants, in stanza four of "Survival" the poet's more ambiguous "inland eye" is drawn to "their maze of shapes / their common purple shadow." Though the poem opens in stanza one with the assertion that cedars "thrive" in a grassland environment where no other trees can and where "no one is watching," in fact both the ecologist and the poet are watching. Both the ecologist and the poet view cedar in aesthetic and emotional terms, with Hansen's imagined character of the ecologist interpreting the cedars as unattractive and worthy of contempt, and the poet interpreting them as evocative and worthy of wonder.

While the ecologist imagined in Hansen's poem responds to cedar's spread with physical action, the poet responds with the linguistic action of metaphor. The poet's description of the trees' "wind-battered limbs / clinging to some grand obtuse scheme" links the cedar's limbs with the limbs of a human body and metaphorically imagines them as clinging to an unidentified abstract concept, a "grand obtuse scheme."

Given the settler colonial history, culture, and identities that Hansen and her coauthor, South Dakota rancher and writer Linda Hasselstrom, explore in their book Dirt Songs (2011), this "scheme" can be interpreted as Euro-American settlement on the Great Plains, which involves putting down cultural "roots" in a place where disturbances of wind, climate, and fire may uproot people and plants. The cedar and the poet are linked through the poem's title concept of "Survival," but the poet's critique of the specifically "grand, obtuse" project of settlement suggests that not all kinds of survival on the Great Plains are the same or can be metaphorically equated. An ecocritical attention to the poem's context considers the cultural values held by settlers, e.g., that civilization equals stability and thus requires the correction of an apparently unstable, "deficient" grassland (Kaye 2011). These cultural values impacted settlers' land use practices, as seen in the decreased frequency and intensity of prairie fires and in the planting of trees (Courtwright 2011), which induced and accelerated cedar's range infilling.

Hansen's poem engages this context by distinguishing between human economic and ecological values. The poem first subtly links the imagined ecologist's point of view with that of settler farmers and ranchers in the description of cedars as "Invading / the unplowed field, grassland." Cedar's range infilling is not simply an objective problem in ecology; it is an ecological problem for society because it threatens economic value. This point is also evident in the poem's grammatical construction of "grassland" as another word for an "unplowed field," with the latter idea given priority.

The poem's fifth stanza then challenges the conflation of ecological and economic values with the reminder that cedars provide "refuge" to "Small fauna" and "food / when all else is depleted." In this example the cedars offer ecological value (at least to the small fauna that the poem seems to value) that is not economic value, at least not in human terms. Hansen wonders: "Why is it, then / in our street-wisdom, in our what-we-do mind / we prefer a tendril of the exotic, the world / of orderliness?" The description of orderly species alludes to the introduced crops that settler farmers have preferred to plant in plowed fields of former prairies; this preference is economic "settler common sense" (Rifkin 2014), "what-we-do." Yet cedar causes the poet to question this prioritization of economic value and reflect on its ecological impacts.

The passive construction of the claim that cedar provides "food / when all else is depleted," similarly raises the question of who or what is responsible for the depletion. The poem implies that human actions of farming and introducing new species have impacted grassland environments, and cedar's range infilling is partially a result of those impacts: Juniperus virginiana, like other species, is competing for survival in the grasslands.

Hansen's poem concludes with an affirmation of adaptive survival as favored by "Nature" and as invigorating to the "“weary" poet. The final image of the poet seeing, listening to, and smelling not a beautiful prairie landscape of native grasses and forbs but rather "the stench of one maverick / stiff-needled seedling" is an attempt to acknowledge and resolve the tension between different ways of valuing cedar. Through its descriptions the poem acknowledges that cedar should not be everywhere, but it should be somewhere, and suggests that humans responding to cedars must consider how cedar is valued in aesthetic and emotional as well as economic and ecological terms.

\section{"Rite of the Chiefs"}

Hansen's description of cedar as tough, enduring, and a symbol for life originates in long-standing indigenous or Native American relationships to cedar on the Great Plains. Indigenous peoples' ways of living and knowing can be understood as traditional ecological knowledge (TEK), "a cumulative body of knowledge, practice, and belief, evolving by adaptive processes and handed down through generations by cultural transmission, about the relationship of living beings (including humans) with one another and with their environment" (Berkes et al. 2000:1252). Ethnobiologists, including ethnobotanists, value and engage with TEK in their studies of interactions between human cultures and their environments (Nabhan 2000, 2009, 2016, Turner et al. 2003). In his early 20th-century ethnobotanical entry for Juniperus virginiana, Melvin R. Gilmore ([1919] 1991) provides cedar's names in Dakota, Omaha-Ponca, and Pawnee. In Gilmore's view, because the cedar was "appearing to be withdrawn into lonely places, and standing dark and still, like an Indian with his robe drawn over his head in prayer and meditation" it "seemed to be in communion with the Higher Powers" ([1919] 1991:5). For the Great Plains cultures that Gilmore observed, cedar's appearance and holiness, i.e., its aesthetic and spiritual value, were connected to their knowledge and recognition of cedar's range, "withdrawn into lonely places."

Anthropological documents of oral literary and spiritual traditions of the Osage, another Great Plains culture, show their ways of knowing cedar as a symbol of longevity. In the recitation of "The Gentle Ponca People" clan of the Osage in their complex "Rite of the Chiefs," part of a ceremony used to initiate tribal 
members into the priesthood, the Osage speakers poetically describe what the Grandfather said when gifting them with the symbol of cedar:

Behold, the female red cedar.
Verily, I am a person who has made of that tree my body.
When the little ones make of me their bodies,
They shall always live to see old age.
Behold, the male red cedar.
The little ones shall always use the male red cedar as a
symbol.
Behold the male red cedar.
When the little ones use that tree for a symbol,
They shall always live to see old age. (Bailey 1995:234)

Here, cedar is seen in a sacred perspective: behold. The power of this ritual comes not only from the sound and rhythm of these words in Osage but also from the people's physical performance in the symbolic context of their land: a truly adaptive dance. By accepting the gift of cedar as a symbol and participating in the Grandfather's metaphorical making of that tree into a body, the Osage people (the "little ones") affirm their cultural value of life as made possible through dynamic relations. The Osage's traditional ways of knowing and relating to cedar and other creatures has shaped and continues to shape their interactions with land and vice versa, in what we now understand as a SES.

\section{Language that links humans and cedars}

People's perceptions of problems are important determinants of social responses to those problems (Adams et al. 2003). The spread of cedar in grasslands has resulted in it being described in the scientific literature as an "invasive species" (Walker and Hoback 2007), "deleterious native invasive" (Ansley and Rasmussen 2005), "aggressive invader species” (Sauer et al. 2006), "native expansive" (Crawford and Hoagland 2009), "native species gone rogue" (R. B. Kaul 2015, personal communication), and "woody plant that is rapidly encroaching" (Starks and Moriasi 2017). Descriptors like these imply that cedar is a species that is somehow not normal, i.e., out of place, in its range and behavior (Streit Krug 2013). Indeed, these noun phrases attempt to classify what cedar as a species "is" by isolating it as a singular phenomenon.

Can these invasion-based descriptors be effectively deployed to address cedar spread as an ecological problem? Given the diversity of the aforementioned terms, a prerequisite for doing so is a scientifically precise understanding of invasion terminology. Although commonly associated with economic or environmental harm, an invasive species may be more accurately defined ecologically as a species that is actively increasing its range, i.e., spreading (Richardson et al. 2000). Classifying cedar as an invasive species according to this definition could help challenge policies that enable cedar spread through the promotion of specific management practices, e.g., planting cedar and suppressing fire.

Whether or not invasion-based descriptors are productive for public understanding of invasive species as well as related conservation efforts (Larson 2005, Nay and Brunson 2013, Simberloff 2013), we seek increased knowledge and "responsible framing" of cedar as a complex social-ecological challenge (Davis 2009:168-169). We therefore prioritize language that directly challenges the cultural values of settler societies related to stability and disturbance, which are at the root of cedar spread and numerous other social-ecological challenges (Holling and Meffe 1996, Walker and Salt 2006). Cedar spread is related to human culture and behavior. More broadly, in the context of decolonial thinking, nature tends to be understood as interrelated with culture, which is "the habit-forming practices and politics of connection and disconnection that shape, and are shaped by, the dynamic experiences of being-in-relation-in-the-world(s)" (Rocheleau and Nirmal 2016:55). Our interdisciplinary analysis of cedar in a dynamic SES context leads us to look for language that foregrounds these complex relationships between human cultures and other abiotic and biotic components of SES. The use of culturally induced range infilling to describe cedar places cedar spread in the historical context of Great Plains SES. Naming the problem of cedar as culturally induced range infilling may help society focus on the process of what is unfolding, and humans' role in it, in a way that is ecologically precise and socially responsible (Davis 2009).

But although this four-word term does precisely link humans and cedar, it is, from the standpoints of poetry and plain language, unwieldy. A shorter, simpler descriptor might be "unrestrained." Applying this adjective to cedar shifts the focus of inquiry to questions like the following: What restrained it? When was it restrained? Why is it not restrained anymore? Does it need to be restrained again? Rather than seeking the right noun phrase to label what cedar is, such questions about restraint emphasize verbs of action and relationship to connect human concepts and actions to cedar's spread. These questions thereby evoke the complex ethical choices required in adaptive management (Robinson 2011). Linking the process of restraint to humans - rather than to "nature," per Twidwell et al.'s (2016a) and Kaye's (2011) observations about how settler societies seek to control natureinvites people into deeper self-reflection.

Seeking to simply "command and control" (Holling and Meffe 1996) cedar risks simplifying the ethics of management and risks affirming, rather than addressing, problematic cultural values of Euro-American settlement. Unlike control over something else, self-restraint tends to be a positive ethical value across cultures. So the public use of descriptors based on the value and verb of restraint may support the integration of perspectives from different disciplines and cultures. For instance, given the militaristic settler colonial context of the Great Plains, it would likely be more appropriate and effective for Euro-American researchers and communities to discuss cedar spread with indigenous researchers and communities by using linguistic frames of restraint rather than invasion. Restraint-based language could provide a common vocabulary for crossdisciplinary and interdisciplinary communication, as well as an ethical framework for cross-cultural communication, decisionmaking, and management.

\section{RECLASSIFYING A PROBLEM}

Separating understanding of change in natural systems, i.e., problems in ecology, from social effects and responses, i.e., ecological problems, is not an effective means of addressing social-ecological challenges (Westley et al. 2002, Folke 2007). Instead, integrative approaches, which draw from a diversity of disciplines (Ludwig et al. 2001, Levin 2006) in recognizing the 
inextricable links between people and nature, are needed. We have synthesized and applied SES thinking and ecocriticism-two interdisciplinary approaches to problem solving - to the case of cedar spread in the North American Great Plains.

In sifting among the numerous abiotic, biotic, and spatial factors that have shaped cedar's past and present ranges in Great Plains landscapes, we concur with a number of existing studies (e.g., Fuhlendorf et al. 1996, 2008, Briggs et al. 2002, Ratajczak et al. 2014, Twidwell et al. 2016a) in concluding that human manipulation of fire regimes, in both setting and suppressing fires, has been the primary determinant of cedar's range over at least the past several centuries. By linking current ecological state shifts with historical state shifts in human societies, we further demonstrate that at broad spatial and temporal scales, transitions in Great Plains SES due to colonization can be seen as still unfolding. Describing cedar spread as culturally induced range infilling, or using the language of restraint, recognizes the causal social and ecological processes that have influenced cedar in the past and present, and which are expected to shape its future. If society is still within a window for preventing additional rapid and largely irreversible shifts between grassland and woodland states in Great Plains landscapes (Ratajczak et al. 2016), human cultural values about stability and disturbance, especially perceptions of the utilization of fire as a management tool, will be instrumental drivers of future trajectories.

In addition to formal institutions and rules for governing human activities within SES, practices that benefit the long-term coexistence of systems of people and nature, i.e., sustainability, are often informally embedded in local cultures via diverse mechanisms (Ostrom 2005). As part of a larger process of embracing local knowledge in the adaptive management of Great Plains landscapes (Ratajczak et al. 2016), we suggest that future studies actively engage with TEK by involving contemporary indigenous or Native American societies and stakeholders, an example of which is provided in the collaborative stewardship framework proposed between the Nuwuvi (Southern Paiute) and the United States Forest Service (Spoon et al. 2015). These collaborations, or habitual cross-cultural exchanges, could increase the diversity of knowledge, adaptive capacity, and resilience of SES (Turner et al. 2003) for responding to ecological problems, and promote local, placed-based, i.e., spatial, thinking and approaches to living and problem solving (Pierotti and Wildcat 2000). Restraint-based language may be helpful in inviting diverse participants to join studies and in facilitating cross-cultural collaborations about cedar that complement and correct aspects of Western science and resource management practices (Berkes 1999, McGregor 2004).

Changes in Euro-American cultural perceptions of fire use are feasible (Pyne 2004). One recipe for change could be the spatially explicit pairing of changing social norms about fire with financial incentives (Vincent 2007) for managing cedar. The recent development and growth of prescribed burn associations in the Great Plains (Twidwell et al. 2013b, Weir et al. 2016) is an example of the development of social networks that strongly influence bottom-up, community-based management (Crona and Bodin 2012). Ideally, these changing values about fire will be passed down to future generations (Weir et al. 2016) as landowners gain experience with the use of fire as a management tool (Morton et al. 2010). Could such a cultural transformation toward increased acceptance of fire, even extreme fire (Twidwell et al. 2013a, 2016b), as a management tool stave off impending shifts from grass to woody plant dominance (Ratajczak et al. 2016) in Great Plains landscapes? Too often, much needed societal changes for responding to social-ecological challenges are delayed (Scheffer et al. 2003). However, if increases in the number of fires, area of land burned, and spatial scale of fire-based cooperation over time (Twidwell et al. 2013b, Weir et al. 2016) are indicative of progress in achieving cultural change, then at least some degree of success is apparent.

Making wise choices about how to cope with alternative states of ecosystems, as epitomized by the tension between grassland and cedar states in the Great Plains, requires interdisciplinary understanding of the role of human culture. As contemporary society seeks to respond to the culturally induced range infilling of cedar, we suggest that it is not only possible, but preferable, to address cedar spread as both a problem in ecology and an ecological problem. Cedar spread may not be a problem for cedars, but insofar as it is a problem for humans, it is a problem that calls us to engage across disciplinary and cultural boundaries.

\section{Responses to this article can be read online at: http://www.ecologyandsociety.org/issues/responses. $\mathrm{php/9357}$}

\section{Acknowledgments:}

The authors would like to extend special thanks to Kent Fricke, Robert Kaul, Fran Kaye, Tom Lynch, Caleb Roberts, and Daniel Clausen for their contributions and insightful comments on previous versions of this manuscript, as well as the University of Nebraska Center for Great Plains Studies, where A.S.K. and D.R.U. have been graduate fellows. The authors appreciate funding support received from both the Center for Great Plains Studies and Nebraska Game and Parks Commission W-125-5-1. The Nebraska Cooperative Fish and Wildlife Research Unit is jointly supported by a cooperative agreement between the U.S. Geological Survey, the Nebraska Game and Parks Commission, the University of Nebraska-Lincoln, the U.S. Fish and Wildlife Service, and the Wildlife Management Institute. Any use of trade, firm, or product names is for descriptive purposes only and does not imply endorsement by the U.S. Government.

\section{LITERATURE CITED}

Adams, W. M., D. Brockington, J. Dyson, and B. Vira. 2003. Managing tragedies: understanding conflict over common pool resources. Science 302:1915-1916. http://dx.doi.org/10.1126/ science. 1087771

Alberti, M., J. M. Marzluff, E. Shulenberger, G. Bradley, C. Ryan, and C. Zumbrunnen. 2003. Integrating humans into ecology: opportunities and challenges for studying urban ecosystems. Bioscience 53:1169-1179. http://dx.doi.org/10.1641/0006-3568 (2003)053[1169:IHIEOA]2.0.CO;2

Alexander, J. M., and P. J. Edwards. 2010. Limits to the niche and range margins of alien species. Oikos 119:1377-1386. http://dx. doi.org/10.1111/j.1600-0706.2009.17977.x 
Allen, C. R., J. J. Fontaine, K. L. Pope, and A. S. Garmestani. 2011. Adaptive management for a turbulent future. Journal of Environmental Management 92:1339-1345. http://dx.doi.org/10.1016/ j.jenvman.2010.11.019

Allen, M. S., and M. W. Palmer. 2011. Fire history of a prairie/ forest boundary: more than 250 years of frequent fire in a North American tallgrass prairie. Journal of Vegetation Science 22:436-444. http://dx.doi.org/10.1111/j.1654-1103.2011.01278.x

Anderson, R. C. 2006. Evolution and origin of the central grassland of North America: climate, fire, and mammalian grazers. Journal of the Torrey Botanical Society 133:626-647. http://dx.doi.org/10.3159/1095-5674(2006)133[626:EAOOTC]2.0. $\mathrm{CO} ; 2$

Ansley, R. J., and G. A. Rasmussen. 2005. Managing native invasive juniper species using fire. Weed Technology 19:517-522. http://dx.doi.org/10.1614/WT-04-098R1.1

Armitage, D. R., R. Plummer, F. Berkes, R. I. Arthur, A. T. Charles, I. J. Davidson-Hunt, A. P. Diduck, N. C. Doubleday, D. S. Johnson, M. Marschke, P. McConney, E. W. Pinkerton, and E. K. Wollenberg. 2009. Adaptive co-management for socialecological complexity. Frontiers in Ecology and the Environment 7:95-102. http://dx.doi.org/10.1890/070089

Bailey, G. A., editor. 1995. The Osage and the invisible world: from the works of Francis La Flesche. University of Oklahoma Press, Norman, Oklahoma, USA.

Berkes, F. 1999. Sacred ecology: traditional ecological knowledge and resource management. Taylor \& Francis, Philadelphia, Pennsylvania, USA.

Berkes, F., J. Colding, and C. Folke. 2000. Rediscovery of traditional ecological knowledge as adaptive management. Ecological Applications 10:1251-1262. http://dx.doi.org/10.2307/2641280

Berkes, F., and C. Folke. 1998. Linking social and ecological systems for resilience and sustainability. Pages 1-25 in F. Berkes and C. Folke, editors. Linking social and ecological systems: management practices and social mechanisms for building resilience. Cambridge University Press, Cambridge, UK.

Bessey, C. E. 1900. The forests and forest trees of Nebraska. Reprinted from the Annual Report of the Nebraska State Board of Agriculture, 1899. State Journal Company Printers, Lincoln, Nebraska, USA.

Bond, W. J. 2008. What limits trees in $\mathrm{C}_{4}$ grasslands and savannas? Annual Review of Ecology, Evolution, and Systematics 39:641-659. http://dx.doi.org/10.1146/annurev.ecolsys.39.110707.173411

Bond, W. J., and G. F. Midgley. 2012. Carbon dioxide and the uneasy interactions of trees and savannah grasses. Philosophical Transactions of the Royal Society B 367:601-612. http://dx.doi. org/10.1098/rstb.2011.0182

Bond, W. J., F. I. Woodward, and G. F. Midgley. 2005. The global distribution of ecosystems in a world without fire. New Phytologist 165:525-538. http://dx.doi.org/10.1111/j.1469-8137.2004.01252. $\underline{\mathrm{X}}$

Bowman, D. M. J. S., J. Balch, P. Artaxo, W. J. Bond, M. A. Cochrane, C. M. D’Antonio, R. Defries, F. H. Johnston, J. E. Keeley, M. A. Krawchuk, C. A. Kull, M. Mack, M. A. Moritz,
S. Pyne, C. I. Roos, A. C. Scott, N. S. Sodhi, and T. W. Swetnam. 2011. The human dimension of fire regimes on Earth. Journal of Biogeography 38:2223-2236. http://dx.doi.org/10.1111/ j.1365-2699.2011.02595.X

Bradley, B. A., R. Early, and C. J. B. Sorte. 2015. Space to invade? Comparative range infilling and potential range of invasive and native plants. Global Ecology and Biogeography 24:348-359. http:// dx.doi.org/10.1111/geb.12275

Brandle, J. R., L. Hodges, and X. H. Zhou. 2004. Windbreaks in North American agricultural systems. Agroforestry Systems 61:65-78. http://dx.doi.org/10.1023/B:AGFO.0000028990.31801.62

Briggs, J. M., G. A. Hoch, and L. C. Johnson. 2002. Assessing the rate, mechanisms, and consequences of the conversion of tallgrass prairie to Juniperus virginiana forest. Ecosystems 5:578-586. http://dx.doi.org/10.1007/s10021-002-0187-4

Briggs, J. M., A. K. Knapp, J. M. Blair, J. L. Heisler, G. A. Hoch, M. S. Lett, and J. K. McCarron. 2005. An ecosystem in transition: causes and consequences of the conversion of mesic grassland to shrubland. BioScience 55:243-254. http://dx.doi.org/10.1641/0006-3568 (2005)055[0243:AEITCA]2.0.CO;2

Broennimann, O., U. A. Treier, H. Müller-Schärer, W. Thuiller, A. T. Peterson, and A. Guisan. 2007. Evidence of climatic niche shift during biological invasion. Ecology Letters 10:701-709. http://dx.doi.org/10.1111/j.1461-0248.2007.01060.x

Bruno, J. F., J. J. Stachowicz, and M. D. Bertness. 2003. Inclusion of facilitation into ecological theory. Trends in Ecology \& Evolution 18:119-125. http://dx.doi.org/10.1016/S0169-5347(02) $\underline{00045-9}$

Bryson, J. S. 2002. Introduction. Pages 1-13 in J. S. Bryson, editor. Ecopoetry: a critical introduction. University of Utah Press, Salt Lake City, Utah, USA.

Chapin, F. S., III, M. E. Power, S. T. A. Pickett, A. Freitag, J. A. Reynolds, R. B. Jackson, D. M. Lodge, C. Duke, S. L. Collins, A. G. Power, and A. Bartuska. 2011. Earth stewardship: science for action to sustain the human-earth system. Ecosphere 2:1-20. http://dx.doi.org/10.1890/ES11-00166.1

Chase, J. M., and M. A. Leibold. 2003. Ecological niches: linking classical and contemporary approaches. University of Chicago Press, Chicago, Illinois, USA. http://dx.doi.org/10.7208/ chicago/9780226101811.001.0001

Collins, S. L., S. R. Carpenter, S. M. Swinton, D. E. Orenstein, D. L. Childers, T. L. Gragson, N. B. Grimm, J. M. Grove, S. L. Harlan, J. P. Kaye, A. K. Knapp, G. P. Kofinas, J. J. Magnuson, W. H. McDowell, J. M. Melack, L. A. Ogden, G. P. Robertson, M. D. Smith, and A. C. Whitmer. 2011. An integrated conceptual framework for long-term social-ecological research. Frontiers in Ecology and the Environment 9:351-357. http://dx.doi. org/10.1890/100068

Courtwright, J. 2011. Prairie fire: a Great Plains history. University Press of Kansas, Lawrence, Kansas, USA.

Crawford, P. H. C., and B. W. Hoagland. 2009. Can herbarium records be used to map alien species invasion and native species expansion over the past 100 years? Journal of Biogeography 36:651-661. http://dx.doi.org/10.1111/j.1365-2699.2008.02043.x 
Crona, B., and Ö. Bodin. 2012. Knowledge, social networks and leadership: setting the stage for the development of adaptive institutions? Pages 11-36 in E. Boyd and C. Folke, editors. Adapting institutions: governance, complexity and socialecological resilience. Cambridge University Press, Cambridge, UK. http://dx.doi.org/10.1017/cbo9781139017237.005

Cumming, G. S. 2014. Theoretical frameworks for the analysis of social-ecological systems. Pages 3-24 in S. Sakai and C. Umetsu, editors. Social-ecological systems in transition. Springer, Tokyo, Japan. http://dx.doi.org/10.1007/978-4-431-54910-9 1

D’Odorico, P., F. Laio, and L. Ridolfi. 2006. A probabilistic analysis of fire-induced tree-grass coexistence in savannas. American Naturalist 167:E79-E87. http://dx.doi.org/10.1086/500617

Davidson-Hunt, I. J., and F. Berkes. 2003. Nature and society through the lens of resilience: toward a human-in-ecosystem perspective. Pages 53-82 in F. Berkes, J. Colding, and C. Folke, editors. Navigating social-ecological systems: building resilience for complexity and change. Cambridge University Press, Cambridge, UK. http://dx.doi.org/10.1017/cbo9780511541957.006

Davis, M. A. 2009. Invasion biology. Oxford University Press, Oxford, UK.

Dellasala, D. A., J. E. Williams, C. D. Williams, and J. F. Franklin. 2004. Beyond smoke and mirrors: a synthesis of fire policy and science. Conservation Biology 18:976-986. http://dx.doi. org/10.1111/j.1523-1739.2004.00529.X

De Vos, A., G. S. Cumming, D. Cumming, J. M. Ament, J. Baum, H. Clements, J. Grewar, K. Maciejewski, and C. Moore. 2016. Pathogens, disease, and the social-ecological resilience of protected areas. Ecology and Society 21(1):20. http://dx.doi. org/10.5751/ES-07984-210120

Elton, C. 1927. Animal ecology. Sedgwick and Jackson, London, UK.

Engler, R., and A. Guisan. 2009. MigClim: predicting plant distribution and dispersal in a changing climate. Diversity and Distributions 15:590-601. http://dx.doi.org/10.1111/

j.1472-4642.2009.00566.x

Fitzpatrick, M. C., J. F. Weltzin, N. J. Sanders, and R. R. Dunn. 2007. The biogeography of prediction error: why does the introduced range of the fire ant over-predict its native range? Global Ecology and Biogeography 16:24-33. http://dx.doi. org/10.1111/j.1466-8238.2006.00258.x

Folke, C. 2007. Social-ecological systems and adaptive governance of the commons. Ecological Research 22:14-15. http:// dx.doi.org/10.1007/s11284-006-0074-0

Folke, C., S. R. Carpenter, B. Walker, M. Scheffer, T. Chapin, and J. Rockström. 2010. Resilience thinking: integrating resilience, adaptability and transformability. Ecology and Society 15(4):20. http://dx.doi.org/10.5751/es-03610-150420

Folke, C., T. Hahn, P. Olsson, and J. Norberg. 2005. Adaptive governance of social-ecological systems. Annual Review of Environment and Resources 30:441-473. http://dx.doi.org/10.1146/ annurev.energy.30.050504.144511

Fuhlendorf, S. D., S. A. Archer, F. E. Smeins, D. M. Engle, and C. A. Taylor, Jr. 2008. The combined influence of grazing, fire, and herbaceous productivity on tree-grass interactions. Pages 219-238 in O. W. Van Auken, editor. Western North American Juniperus communities: a dynamic vegetation type. Springer, New York, New York, USA. http://dx.doi.org/10.1007/978-0-387-34003-6_12

Fuhlendorf, S. D., D. M. Engle, J. Kerby, and R. Hamilton. 2009. Pyric herbivory: rewilding landscapes through the recoupling of fire and grazing. Conservation Biology 23:588-598. http://dx.doi. org/10.1111/j.1523-1739.2008.01139.x

Fuhlendorf, S. D., F. E. Smeins, and W. E. Grant. 1996. Simulation of a fire-sensitive ecological threshold: a case study of Ashe juniper on the Edwards Plateau of Texas, USA. Ecological Modelling 90:245-255. http://dx.doi.org/10.1016/0304-3800(95) 00151-4

Gallagher, R. V., L. J. Beaumont, L. Hughes, and M. R. Leishman. 2010. Evidence for climatic niche and biome shifts between native and novel ranges in plant species introduced to Australia. Journal of Ecology 98:790-799. http://dx.doi.org/10.1111/j.1365-2745.2010.01677. $\underline{\mathrm{X}}$

Garrard, G. 2012. Ecocriticism. Second edition. Routledge, London, UK.

Geerts, S., D. Moodley, M. Gaertner, J. J. Le Roux, M. A. McGeoch, C. Muofhe, D. M. Richardson, and J. R. U. Wilson. 2013. The absence of fire can cause a lag phase: the invasion dynamics of Banksia ericifolia (Proteaceae). Austral Ecology 38:931-941. http://dx.doi.org/10.1111/aec.12035

Gilmore, M. R. [1919] 1991. Uses of plants by the Indians of the Missouri River region. University of Nebraska Press, Lincoln, Nebraska, USA.

González-Moreno, P., J. M. Dietz, D. M. Richardson, and M. Vilà. 2015. Beyond climate: disturbance niche shifts in invasive species. Global Ecology and Biogeography 24:360-370. http://dx. doi.org/10.1111/geb.12271

Grimm, N. B., J. Morgan Grove, S. T. A. Pickett, and C. L. Redman. 2000. Integrated approaches to long-term studies of urban ecological systems. Bioscience 50:571-584. http://dx.doi. org/10.1641/0006-3568(2000)050[0571:IATLTO]2.0.CO;2

Grinnell, J. 1917. The niche-relationships of the California Thrasher. Auk 34:427-433. http://dx.doi.org/10.2307/4072271

Groisman, P. Y., R. W. Knight, and T. R. Karl. 2012. Changes in intense precipitation over the central United States. Journal of Hydrometeorology 13:47-66. http://dx.doi.org/10.1175/JHMD-11-039.1

Gunderson, L. H. 2003. Adaptive dancing: interactions between social resilience and ecological crises. Pages 33-52 in F. Berkes, J. Colding, and C. Folke, editors. Navigating social-ecological systems: building resilience for complexity and change. Cambridge University Press, Cambridge, UK. http://dx.doi.org/10.1017/ cbo9780511541957.005

Hahn, T., P. Olsson, C. Folke, and K. Johansson. 2006. Trustbuilding, knowledge generation and organizational innovations: the role of a bridging organization for adaptive comanagement of a wetland landscape around Kristianstad, Sweden. Human Ecology 34:573-592. http://dx.doi.org/10.1007/s10745-006-9035$\underline{Z}$ 
Hansen, T. M. 2011. Survival. Pages 9-10 in T. M. Hansen and L. M. Hasselstrom. Dirt songs: a plains duet. Backwaters Press, Omaha, Nebraska, USA.

Hansen, T. M., and L. M. Hasselstrom. 2011. Dirt songs: a plains duet. Backwaters Press, Omaha, Nebraska, USA.

Harr, R. N., L. Wright Morton, S. R. Rusk, D. M. Engle, J. R. Miller, and D. Debinski. 2014. Landowners' perception of risk in grassland management: woody plant encroachment and prescribed fire. Ecology and Society 19(2):41. http://dx.doi. org/10.5751/ES-06404-190241

Hass, R. 2013. American ecopoetry: an introduction. Pages xli$\mathrm{lxv}$ in A. Fisher-Wirth and L. Street, editors. The ecopoetry anthology. Trinity University Press, San Antonio, Texas, USA.

Hawbaker, T. J., V. C. Radeloff, S. I. Stewart, R. B. Hammer, N. S. Keuler, and M. K. Clayton. 2013. Human and biophysical influences on fire occurrence in the United States. Ecological Applications 23:565-582. http://dx.doi.org/10.1890/12-1816.1

Heise, U. K. 2006. The hitchhiker's guide to ecocriticism. PMLA 121:503-516. http://dx.doi.org/10.1632/003081206X129684

Hirzel, A. H., and G. Le Lay. 2008. Habitat suitability modelling and niche theory. Journal of Applied Ecology 45:1372-1381. http:// dx.doi.org/10.1111/j.1365-2664.2008.01524.X

Hoekstra, J. M., T. M. Boucher, T. H. Ricketts, and C. Roberts. 2005. Confronting a biome crisis: global disparities of habitat loss and protection. Ecology Letters 8:23-29. http://dx.doi. org/10.1111/j.1461-0248.2004.00686.X

Holling, C. S. 2003. Forward: the backloop to sustainability. Pages xv-xxi in F. Berkes, J. Colding, and C. Folke, editors. Navigating social-ecological systems: building resilience for complexity and change. Cambridge University Press, Cambridge, UK.

Holling, C. S., and G. K. Meffe. 1996. Command and control and the pathology of natural resource management. Conservation Biology 10:328-337. http://dx.doi.org/10.1046/j.1523-1739.1996.10020328. $\underline{\mathrm{X}}$

Holling, C. S., and S. Sanderson. 1996. Dynamics of (dis) harmony in ecological and social systems. Pages 57-86 in S. Hanna, C. Folke, and K.-G. Mäler, editors. Rights to nature: ecological, economic, cultural, and political principles of institutions for the environment. Island Press, Washington, D.C., USA.

Holm, P., J. Adamson, H. Huang, L. Kirdan, S. Kitch, I. McCalman, J. Ogude, M. Ronan, D. Scott, K. O. Thompson, C. Travis, and K. Wehner. 2015. Humanities for the environment: a manifesto for research and action. Humanities 4:977-992. http:// dx.doi.org/10.3390/h4040977

Holt, R. D. 2009. Bringing the Hutchinsonian niche into the 21st century: ecological and evolutionary perspectives. Proceedings of the National Academy of Sciences, USA 106:19659-19665. http:// dx.doi.org/10.1073/pnas.0905137106

Horncastle, V. J., E. C. Hellgren, P. M. Mayer, D. M. Engle, and D. M. Leslie, Jr. 2004. Differential consumption of eastern red cedar (Juniperus virginiana) by avian and mammalian guilds: implications for tree invasion. American Midland Naturalist
152:255-267. https://doi.org/10.1674/0003-0031(2004)152[0255: DCOERC]2.0.CO;2

Huntley, B., and R. Baxter. 2013. Vegetation ecology and global change. Pages 509-530 in E. van der Maarel and J. Franklin, editors. Vegetation ecology. Second edition. Wiley-Blackwell, Chichester, UK. http://dx.doi.org/10.1002/9781118452592.ch17

Hutchinson, G. E. 1957. Concluding remarks. Cold Springs Harbor Symposium. Quantitative Biology 22:415-427. http://dx. doi.org/10.1101/SQB.1957.022.01.039

Hutchinson, G. E. 1978. An introduction to population ecology. Yale University Press, New Haven, Connecticut, USA.

Jones, N. A., S. Shaw, H. Ross, K. Witt, and B. Pinner. 2016. The study of human values in understanding and managing socialecological systems. Ecology and Society 21(1):15. http://dx.doi. org/10.5751/ES-07977-210115

Kaye, F. W. 2011. Goodlands: a meditation and history on the Great Plains. AU Press, Edmonton, Alberta, Canada.

Kendrick, A. 2003. Caribou co-management in northern Canada: fostering multiple ways of knowing. Pages 241-268 in F. Berkes, J. Colding, and C. Folke, editors. Navigating social-ecological systems: building resilience for complexity and change. Cambridge University Press, Cambridge, UK. http://dx.doi.org/10.1017/ cbo9780511541957.015

Kharouba, H. M., A. C. Algar, and J. T. Kerr. 2009. Historically calibrated predictions of butterfly species' range shift using global change as a pseudo-experiment. Ecology 90:2213-2222. http://dx. doi.org/10.1890/08-1304.1

Knapp, A. K., J. K. McCarron, A. M. Silletti, G. A. Hoch, J. C. Heisler, M. S. Lett, J. M. Blair, J. M. Briggs, and M. D. Smith. 2008. Ecological consequences of the replacement of native grassland by Juniperus virginiana and other woody plants. Pages 156-169 in O. W. Van Auken, editor. Western North American Juniperus communities: a dynamic vegetation type. Springer, New York, New York, USA. http://dx.doi.org/10.1007/978-0-387-34003-6_8

Knickerbocker, S. 2012. Ecopoetics: the language of nature, the nature of language. University of Massachusetts Press, Amherst, Massachusetts, USA.

Laris, P., S. Caillault, S. Dadashi, and A. Jo. 2015. The human ecology and geography of burning in an unstable savanna environment. Journal of Ethnobiology 35:111-139. http://dx.doi. org/10.2993/0278-0771-35.1.111

Larson, B. M. H. 2005. The war of the roses: demilitarizing invasion biology. Frontiers in Ecology and the Environment 3:495-500. http://dx.doi.org/10.1890/1540-9295(2005)003[0495: TWOTRD]2.0.CO;2

Lawson, E. R. 1990. Juniperus virginiana L. Eastern redcedar. Pages 240-259 in R. M. Burns and B. H. Honkala, technical coordinators. The silvics of North America: 1. Conifers; 2. Hardwoods. Agricultural Handbook 654. U.S. Forest Service, Washington, D.C., USA.

Ledford, H. 2015. How to solve the world's biggest problems. Nature 525:308-311. http://dx.doi.org/10.1038/525308a 
Levin, S. A. 2006. Learning to live in a global commons: socioeconomic challenges for a sustainable environment. Ecological Research 21:328-333. http://dx.doi.org/10.1007/ s11284-006-0162-1

Liu, J., T. Dietz, S. R. Carpenter, M. Alberti, C. Folke, E. Moran, A. N. Pell, P. Deadman, T. Kratz, J. Lubchenco, E. Ostrom, Z. Ouyang, W. Provencher, C. L. Redman, S. H. Schneider, and W. W. Taylor. 2007. Complexity of coupled human and natural systems. Science 317:1513-1516. http://dx.doi.org/10.1126/ science. 1144004

Ludwig, D., M. Mangel, and B. Haddad. 2001. Ecology, conservation, and public policy. Annual Review of Ecology and Systematics 32:481-517. http://dx.doi.org/10.1146/annurev. ecolsys.32.081501.114116

McCay, B. J. 2002. Emergence of institutions for the commons: contexts, situations, and events. Pages 361-402 in E. Ostrom, T. Dietz, N. Dolsak, P. C. Stern, S. Stonich, and E. U. Weber, editors. The drama of the commons. National Academy Press, Washington, D.C., USA.

McGregor, D. 2004. Coming full circle: indigenous knowledge, environment, and our future. American Indian Quarterly 28:385-410. http://dx.doi.org/10.1353/aiq.2004.0101

McKinley, D. C., and J. M. Blair. 2008. Woody plant encroachment by Juniperus virginiana in a mesic native grassland promotes rapid carbon and nitrogen accrual. Ecosystems 11:454-468. http://dx.doi.org/10.1007/s10021-008-9133-4

Meneguzzo, D. M., and G. C. Liknes. 2015. Status and trends of eastern redcedar (Juniperus virginiana) in the Central United States: analyses and observations based on forest inventory and analysis data. Journal of Forestry 113:325-334. http://dx.doi. org/10.5849/jof.14-093

Miller, J. R., L. W. Morton, D. M. Engle, D. M. Debinski, and R. N. Harr. 2012. Nature reserves as catalysts for landscape change. Frontiers in Ecology and the Environment 10:144-152. http://dx. doi.org/10.1890/100227

Miller, T. R., T. D. Baird, C. M. Littlefield, G. Kofinas, F. S. Chapin III, and C. L. Redman. 2008. Epistemological pluralism: reorganizing interdisciplinary research. Ecology and Society 13 (2):46. http://dx.doi.org/10.5751/es-02671-130246

Morton, L. W., E. Regen, D. M. Engle, J. R. Miller, and R. N. Harr. 2010. Perceptions of landowners concerning conservation, grazing, fire, and eastern redcedar in tallgrass prairie management. Rangeland Ecology and Management 63:645-654. http://dx.doi.org/10.2111/REM-D-09-00041.1

Munguía, M., C. Rahbek, T. F. Rangel, J. A. F. Diniz-Filho, and M. B. Araújo. 2012. Equilibrium of global amphibian species distributions with climate. PLoS ONE 7:e34420. http://dx.doi. org/10.1371/journal.pone.0034420

Murphy, S. D. 2013. Perspective: plus ça change, plus c'est la même chose. Pages 150-151 in R. J. Hobbs, E. S. Higgs, and C. M. Hall, editors. Novel ecosystems: intervening in the new ecological world order. Wiley-Blackwell, Chichester, UK. http://dx.doi. org/10.1002/9781118354186.ch16
Myers, J. A., and K. E. Harms. 2011. Seed arrival and ecological filters interact to assemble high-diversity plant communities. Ecology 92:676-686. http://dx.doi.org/10.1890/10-1001.1

Nabhan, G. P. 2000. Interspecific relationships affecting endangered species recognized by O'Odham and Comcáac cultures. Ecological Applications 10:1288-1295. http://dx.doi. org/10.2307/2641284

Nabhan, G. P. 2009. Ethnoecology: bridging disciplines, cultures and species. Journal of Ethnobiology 29:3-7. http://dx.doi. org/10.2993/0278-0771-29.1.3

Nabhan, G. P. 2016. Introduction: letter to young ethnobiologists. Pages 3-9 in G. P. Nabhan, editor. Ethnobiology for the future: linking cultural and ecological diversity. University of Arizona Press, Tucson, Arizona, USA.

Nay, C. G., and M. W. Brunson. 2013. A war of words: do conflict metaphors affect beliefs about managing "unwanted" plants? Societies 3:158-169. http://dx.doi.org/10.3390/soc3020158

Ostrom, E. 2005. Understanding institutional diversity. Princeton University Press, Princeton, New Jersey, USA.

Passmore, J. 1974. Man's responsibility for nature: ecological problems and Western traditions. Duckworth, London, UK.

Pearman, P. B., A. Guisan, O. Broennimann, and C. F. Randin. 2008. Niche dynamics in space and time. Trends in Ecology and Evolution 23:149-158. http://dx.doi.org/10.1016/j.tree.2007.11.005

Pearson, R. G., and T. P. Dawson. 2003. Predicting the impacts of climate change on the distribution of species: are bioclimatic envelope models useful? Global Ecology and Biogeography 12:361-371. http://dx.doi.org/10.1046/j.1466-822X.2003.00042. $\underline{\mathrm{X}}$

Perring, M. P., P. Manning, R. J. Hobbs, A. E. Lugo, C. E. Ramalho, and R. J. Standish. 2013. Novel urban ecosystems and ecosystem services. Pages 310-325 in R. J. Hobbs, E. S. Higgs, and C. M. Hall, editors. Novel ecosystems: intervening in the new ecological world order. Wiley-Blackwell, Oxford, UK. http://dx. doi.org/10.1002/9781118354186.ch38

Peterson, A. T., J. Soberón, R. G. Pearson, R. P. Anderson, E. Martínez-Meyer, M. Nakamura, and M. B. Araújo. 2011. Ecological niches and geographic distributions. Princeton University Press, Princeton, New Jersey, USA.

Pierce, S., A. Luzzaro, M. Caccianiga, R. M. Ceriani, and B. Cerabolini. 2007. Disturbance is the principle a-scale filter determining niche differentiation, coexistence and biodiversity in an alpine community. Journal of Ecology 95:698-706. http://dx. doi.org/10.1111/j.1365-2745.2007.01242.X

Pierotti, R., and D. Wildcat. 2000. Traditional ecological knowledge: the third alternative (commentary). Ecological Applications 10:1333-1340. http://dx.doi.org/10.2307/2641289

Pulliam, H. R. 2000. On the relationship between niche and distribution. Ecology Letters 3:349-361. http://dx.doi.org/10.1046/ j.1461-0248.2000.00143.x

Pyne, S. J. 2004. Tending fire: coping with America's wildland fires. Island Press, Washington, D.C., USA. 
Ratajczak, Z., J. M. Briggs, D. G. Goodin, L. Luo, R. L. Mohler, J. B. Nippert, and B. Obermeyer. 2016. Assessing the potential for transitions from tallgrass prairie to woodlands: are we operating beyond critical fire thresholds? Rangeland Ecology and Management 69:280-287. http://dx.doi.org/10.1016/j.rama.2016.03.004

Ratajczak, Z., J. B. Nippert, J. M. Briggs, and J. M. Blair. 2014. Fire dynamics distinguish grasslands, shrublands and woodlands as alternative attractors in the Central Great Plains of North America. Journal of Ecology 102:1374-1385. http://dx.doi. org/10.1111/1365-2745.12311

Richardson, D. M., P. Pyšek, M. Rejmánek, M. G. Barbour, F. D. Panetta, and C. J. West. 2000. Naturalization and invasion of alien plants: concepts and definitions. Diversity and Distributions 6:93-107. http://dx.doi.org/10.1046/j.1472-4642.2000.00083.x

Rifkin, M. 2014. Settler common sense: queerness and everyday colonialism in the American Renaissance. University of Minnesota Press, Minneapolis, Minnesota, USA. http://dx.doi.org/10.5749/ minnesota/9780816690572.001.0001

Robinson, J. G. 2011. Ethical pluralism, pragmatism, and sustainability in conservation practice. Biological Conservation 144:958-965. http://dx.doi.org/10.1016/j.biocon.2010.04.017

Rocheleau, D., and P. Nirmal. 2016. Culture. Pages 50-55 in J. Adamson, W. A. Gleason, and D. N. Pellow, editors. Keywords for environmental studies. New York University Press, New York, New York, USA.

Sauer, T. J., C. A. Cambardella, and D. W. Meek. 2006. Spatial variation of soil properties related to vegetation properties. Plant and Soil 280:1-5. http://dx.doi.org/10.1007/s11104-005-1545-8

Scheffer, M., and S. R. Carpenter. 2003. Catastrophic regime shifts in ecosystems: linking theory to observation. Trends in Ecology and Evolution 18:648-656. http://dx.doi.org/10.1016/j. $\underline{\text { tree.2003.09.002 }}$

Scheffer, M., F. Westley, and W. Brock. 2003. Slow response of societies to new problems: causes and costs. Ecosystems 6:493-502. http://dx.doi.org/10.1007/PL00021504

Schurr, F. M., G. F. Midgely, A. G. Rebelo, G. Reeves, P. Poschlod, and S. I. Higgins. 2007. Colonization and persistence ability explain the extent to which plant species fill their potential range. Global Ecology and Biogeography 16:449-459. http://dx.doi. org/10.1111/j.1466-8238.2006.00293.x

Scigaj, L. M. 1999. Sustainable poetry: four American ecopoets. University Press of Kentucky, Lexington, Kentucky, USA.

Shafer, M., D. Ojima, J. M. Antle, D. Kluck, R. A. McPherson, S. Petersen, B. Scanlon, and K. Sherman. 2014. Great Plains. Pages 441-461 in J. M. Melillo, T. C. Richmond, and G. W. Yohe, editors. Climate change impacts in the United States: the third national climate assessment. U.S. Global Change Research Program, Washington, D.C., USA.

Simberloff, D. 2013. Invasive species: what everyone needs to know. Oxford University Press, New York, New York, USA.

Soberón, J. 2007. Grinnellian and Eltonian niches and geographic distributions of species. Ecology Letters 10:1115-1123. http://dx. doi.org/10.1111/j.1461-0248.2007.01107.x
Soberón, J. and M. Nakamura. 2009. Niches and distributional areas: concepts, methods, and assumptions. Proceedings of the National Academy of Sciences 106:19644-19650. http://dx.doi. org/10.1073/pnas.0901637106

Soberón, J., and A. T. Peterson. 2005. Interpretation of models of fundamental ecological niches and species' distributional areas. Biodiversity Informatics 2:1-10. http://dx.doi.org/10.17161/ bi.v2i0.4

Spoon, J., R. Arnold, B. J. Lefler, and C. Milton. 2015. Nuwuvi (Southern Paiute), shifting fire regimes, and the Carpenter One Fire in the Spring Mountains National Recreation Area, Nevada. Journal of Ethnobiology 35:85-110. http://dx.doi. org/10.2993/0278-0771-35.1.85

Stambaugh, M. C., R. P. Guyette, and J. Marschall. 2013. Fire history in the Cherokee Nation of Oklahoma. Human Ecology 41:749-758. http://dx.doi.org/10.1007/s10745-013-9571-2

Starks, P. J., and D. N. Moriasi. 2017. Impact of Eastern redcedar encroachment on stream discharge in the North Canadian River basin. Journal of Soil and Water Conservation 72:12-25. http://dx. doi.org/10.2489/jswc.72.1.12

Steffen, W., K. Richardson, J. Rockström, S. E. Cornell, I. Fetzer, E. M. Bennett, R. Biggs, S. R. Carpenter, W. de Vries, C. A. de Wit, C. Folke, D. Gerten, J. Heinke, G. M. Mace, L. M. Persson, V. Ramanathan, B. Reyers, and S. Sörlin. 2015. Planetary boundaries: guiding human development on a changing planet. Science 347(6223). http://dx.doi.org/10.1126/science.1259855

Streit Krug, A. 2013. Reproducing plant bodies on the Great Plains. Pages 243-264 in R. Laist, editor. Plants and literature: essays in critical plant studies. Rodopi Press, Amsterdam, The Netherlands.

Tang, Z., Y. Gu, J. Drahota, T. LaGrange, A. Bishop, and M. S. Kuzila. 2015. Using fly ash as a marker to quantify culturallyaccelerated sediment accumulation in playa wetlands. Journal of the American Water Resources Association 51:1643-1655. http:// dx.doi.org/10.1111/1752-1688.12347

Taylor, C. A. Jr., D. Twidwell, N. E. Garza, C. Rosser, J. K. Hoffman, and T. D. Brooks. 2012. Long-term effects of fire, livestock herbivory removal, and weather variability in Texas semiarid savanna. Rangeland Ecology and Management 65:21-30. http://dx.doi.org/10.2111/REM-D-10-00124.1

Travis, J. M. J., R. W. Brooker, and C. Dytham. 2005. The interplay of positive and negative species interactions across an environmental gradient: insights from an individual-based simulation model. Biology Letters 1:5-8. http://dx.doi. org/10.1098/rsbl.2004.0236

Turner, M. G. 2010. Disturbance and landscape dynamics in a changing world. Ecology 91:2833-2849. http://dx.doi. org/10.1890/10-0097.1

Turner, M. G., R. H. Gardner, and R. V. O'Neill. 2001. Landscape ecology in theory and practice: pattern and process. SpringerVerlag, New York, New York, USA.

Turner, N. J., I. J. Davidson-Hunt, and M. O'Flaherty. 2003. Living on the edge: ecological and cultural edges as sources of 
diversity for social-ecological resilience. Human Ecology 31:439-461. http://dx.doi.org/10.1023/A:1025023906459

Twidwell, D., S. D. Fuhlendorf, C. A. Taylor Jr., and W. E. Rogers. 2013a. Refining thresholds in coupled fire-vegetation models to improve management of encroaching woody plants in grasslands. Journal of Applied Ecology 50:603-613. http://dx.doi. org/10.1111/1365-2664.12063

Twidwell, D., W. E. Rogers, S. D. Fuhlendorf, C. L. Wonkka, D. M. Engle, J. R. Weir, U. P. Kreuter, and C. A. Taylor Jr. $2013 b$. The rising Great Plains fire campaign: citizens' response to woody plant encroachment. Frontiers in Ecology and the Environment 11: e64-e71. http://dx.doi.org/10.1890/130015

Twidwell, D., W. E. Rogers, C. L. Wonkka, C. A. Taylor Jr., and U. P. Kreuter. 2016b. Extreme prescribed fire during drought reduces survival and density of woody resprouters. Journal of Applied Ecology 53:1585-1596. http://dx.doi.org/10.1111/1365-2664.12674

Twidwell, D., A. S. West, W. B. Hiatt, A. L. Ramirez, J. Taylor Winter, D. M. Engle, S. D. Fuhlendorf, and J. D. Carlson. $2016 a$. Plant invasions or fire policy: which has altered fire behavior more in tallgrass prairie? Ecosystems 19:356-368. http://dx.doi. org/10.1007/s10021-015-9937-y

Václavík, T., and R. K. Meentemeyer. 2012. Equilibrium or not? Modelling potential distribution of invasive species in different stages of invasion. Diversity and Distributions 18:73-83. http://dx. doi.org/10.1111/j.1472-4642.2011.00854.X

van Langevelde, F., C. A. D. M. van de Vijver, L. Kumar, J. van de Koppel, N. De Ridder, J. Van Andel, A. K. Skidmore, J. W. Hearne, L. Stroosnijder, W. J. Bond, H. H. T. Prins, and M. Rietkerk. 2003. Effects of fire and herbivory on the stability of savanna ecosystems. Ecology 84:337-350. http://dx.doi. org/10.1890/0012-9658(2003)084[0337:EOFAHO]2.0.CO;2

Vincent, J. R. 2007. Spatial dynamics, social norms, and the opportunity of the commons. Ecological Research 22:3-7. http:// dx.doi.org/10.1007/s11284-006-0070-4

Volder, A., D. D. Briske, and M. G. Tjoelker. 2013. Climate warming and precipitation redistribution modify tree-grass interactions and tree species establishment in a warm-temperate savanna. Global Change Biology 19:843-857. http://dx.doi. org $/ 10.1111 /$ gcb.12068

Walker, B., C. S. Holling, S. R. Carpenter, and A. Kinzig. 2004. Resilience, adaptability and transformability in social-ecological systems. Ecology and Society 9(2):5. http://dx.doi.org/10.5751/ es-00650-090205

Walker, B., and D. Salt. 2006. Resilience thinking: sustaining ecosystems and people in a changing world. Island Press, Washington, D.C., USA.

Walker, T. L., Jr, and W. W. Hoback. 2007. Effect of invasive eastern redcedar on capture rates of Nicrophorus americanus and other Silphidae. Environmental Entomology 36:297-307. http://dx. doi.org/10.1093/ee/36.2.297

Weir, J. R., D. Twidwell, and C. L. Wonkka. 2016. From grassroots to national alliance: the emerging trajectory for landowner prescribed burn associations. Rangelands 38:113-119. http://dx. doi.org/10.1016/j.rala.2016.02.005
Westley, F., S. R. Carpenter, W. A. Brock, C. S. Holling, and L. H. Gunderson. 2002. Why systems of people and nature are not just social and ecological systems. Pages 103-119 in L. H. Gunderson, and C. S. Holling, editors. Panarchy: understanding transformations in human and natural systems. Island Press, Washington, D.C., USA.

Wiens, J. J., D. D. Ackerly, A. P. Allen, B. L. Anacker, L. B. Buckley, H. V. Cornell, E. I. Damschen, T. J. Davies, J.-A. Grytnes, S. P. Harrison, B. A. Hawkins, R. D. Holt, C. M. McCain, and P. R. Stephens. 2010. Niche conservatism as an emerging principle in ecology and conservation biology. Ecology Letters 13:1310-1324. http://dx.doi.org/10.1111/j.1461-0248.2010.01515.x

Wishart, D. J. 1995. An unspeakable sadness: the dispossession of the Nebraska Indians. University of Nebraska Press, Lincoln, Nebraska, USA.

White, P. S., and A. Jentsch. 2004. Disturbance, succession, and community assembly in terrestrial plant communities. Pages 342-366 in V. M. Temperton, R. J. Hobbs, T. Nuttle, and S. Halle, editors. Assembly rules and restoration ecology: bridging the gap between theory and practice. Island Press, Washington, D.C., USA.

Witte, S. S., and M. V. Gallagher, editors. 2010. The North American journals of Prince Maximilian of Wied: Volume 2 AprilSeptember 1833. University of Oklahoma Press, Norman, Oklahoma, USA. 
Appendix 1. Twyla Hansen, the Nebraska, USA State Poet, reciting her poem "Survival."

Please click here to download file 'appendixl.wav'. 